\title{
Human Health Risk Assessment of Some Selected Heavy Metals in Brassica rapa var. parachinensis in Peninsular Malaysia
}

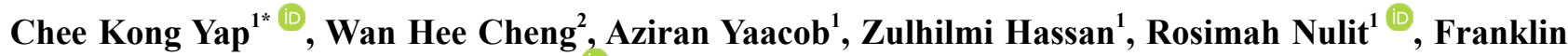 \\ Berandah Edward $^{3}$, Koe Wei Wong ${ }^{1}$, Mohamed Hafiz Ibrahim ${ }^{1}$, Shih Hao Tony Peng ${ }^{4}$, Chee Wah

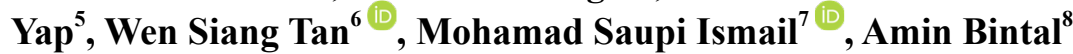 \\ ${ }^{1}$ Department of Biology, Faculty of Science, University of Putra Malaysia, 43400 UPM, Serdang, Selangor, Malaysia \\ ${ }^{2}$ Inti International University, Persiaran Perdana BBN, Nilai, Negeri Sembilan, Malaysia \\ ${ }^{3}$ Natural Resources and Environment Board, Petra Jaya, 93050 Kuching, Sarawak, Malaysia \\ ${ }^{4}$ All Cosmos Bio-Tech Holding Corporation, PLO650, Jalan Keluli, Pasir Gudang Industrial Estate, 81700 Pasir Gudang, Johor, \\ Malaysia \\ ${ }^{5}$ MES SOLUTIONS, 22C-1, Jalan BK 5A/2A, Bandar Kinrara, 47100 Puchong, Selangor, Malaysia \\ ${ }^{6}$ Department of Microbiology, Faculty of Biotechnology and Biomolecular Sciences, University of Putra Malaysia, 43400 UPM \\ Serdang, Selangor, Malaysia \\ ${ }^{7}$ Fisheries Research Institute, Batu Maung, Pulau Pinang 11960, Malaysia \\ ${ }^{8}$ Fisheries and Marine Science Faculty, University of Riau, Pekanbaru, Riau, Indonesia \\ E-mail: yapckong@hotmail.com; yapchee@upm.edu.my
}

Received: 10 July 2021; Revised: 16 September 2021; Accepted: 28 September 2021

\begin{abstract}
Biomonitoring of heavy metals is an important part of the ecotoxicological study. However, without the application of the metal data to reflect human wellbeing, it is considered the low impact on the society. In this study, the heavy metals in green mustard Brassica rapa var. parachinensis were collected from Sikamat (Negeri Sembilan in 2013), Kg. Sitiawan (Perak in 2016), and Ara Kuda (Penang in 2016) of Peninsular Malaysia, were determined. The samples are analyzed for the concentrations of $\mathrm{Cu}, \mathrm{Fe}, \mathrm{Ni}, \mathrm{Pb}$, and $\mathrm{Zn}$ by using the flame atomic absorption spectrophotometer. For the leafy edible part, the metal concentrations $(\mathrm{mg} / \mathrm{kg}$ dry weight) ranged from 16.1-18.5 for $\mathrm{Cu}, 145-207$ for $\mathrm{Fe}, 1.02-1.64$ for $\mathrm{Ni}, 0.90-2.73$ for $\mathrm{Pb}$, and 74.0-203 for $\mathrm{Zn}$. These metal data were assessed for human health risks. It was found that all the values of target hazard quotients for $\mathrm{Cu}, \mathrm{Fe}, \mathrm{Ni}, \mathrm{Pb}$, and $\mathrm{Zn}$ in both adults and children were less than 1.00. This exhibited there were no non-carcinogenic risks of the five metals through the intake of the Brassica from the present study. This could indicate that the accumulation of metals and pollution threshold is below the limit of causing hazardous effects to consumers. Nonetheless, regular assessment of health risks of heavy metals in this vegetable needs to be conducted from time to time these vegetables are prone to continuous heavy metal contamination.
\end{abstract}

Keywords: green mustard, heavy metals, human health risk

\section{Introduction}

In the ecotoxicological study, heavy metal (HM) biomonitoring in vegetables is very important from the perspective

Copyright (C2021 Chee Kong Yap, et al.

DOI: https://doi.org/10.37256/fse.2220211036

This is an open-access article distributed under a CC BY license

(Creative Commons Attribution 4.0 International License)

https://creativecommons.org/licenses/by/4.0/ 
of provision of basic information of the current status of HM pollution. However, if only the biomonitoring data is to be presented as baseline information for future reference, it is considered low impact on the society. Hence, the application of HM data of the commercial vegetables to human health risk assessment would be of relevance to human wellbeing.

This is evident, as many HM data in vegetables have been assessed for the human health risks of heavy metals, particularly in west Peninsular Malaysia [1-6]. which provides a more accurate estimation of hazardous effects through consumption. This implies the importance of such monitoring of HMs in vegetables. Vegetables have been highly consumed nowadays as daily food intake. However, the major concern of the public is vegetables contaminated with HMs which is a major route to the human body [7-8]. The food chain is an important route, through which HMs are transferred from vegetables to consumers [9]. There has also been an increasing health concern through the consumption of vegetables that are irrigated with HMs contaminated wastewater [10]. Therefore, the question of 'If the vegetable Brassica is safe from HM contamination?' could be raised.

The purpose of this study was to assess the human health risks of $\mathrm{Fe}, \mathrm{Cu}, \mathrm{Ni}, \mathrm{Pb}$, and $\mathrm{Zn}$ in Brassica rapa var. parachinensis from three farming sites in Peninsular Malaysia.

\section{Materials and methods}

A sampling of B. rapa var. parachinensis was conducted in three farming sites in Peninsular Malaysia, namely Sikamat (Negeri Sembilan; September 2013), Ara Kuda (Penang; October 2016), and Kg. Sitiawan (Perak; October 2016) (Figure 1). Upon collection, the vegetables were stored in clean plastic bags before being sent to the laboratory for further analysis. Methods proposed by Chin and Yap [11] were used to determine the species based on its morphology and classification [12-13].

In the laboratory, the samples were cleaned with distilled water to eliminate soil particles. The leafy parts were then cut into small pieces with a clean knife and dried at a temperature of $60^{\circ} \mathrm{C}$ for 72 hours in an oven until constant dry weights were achieved. The vegetable samples were dried and ground in a commercial blender before being stored in plastic bags for later analysis.

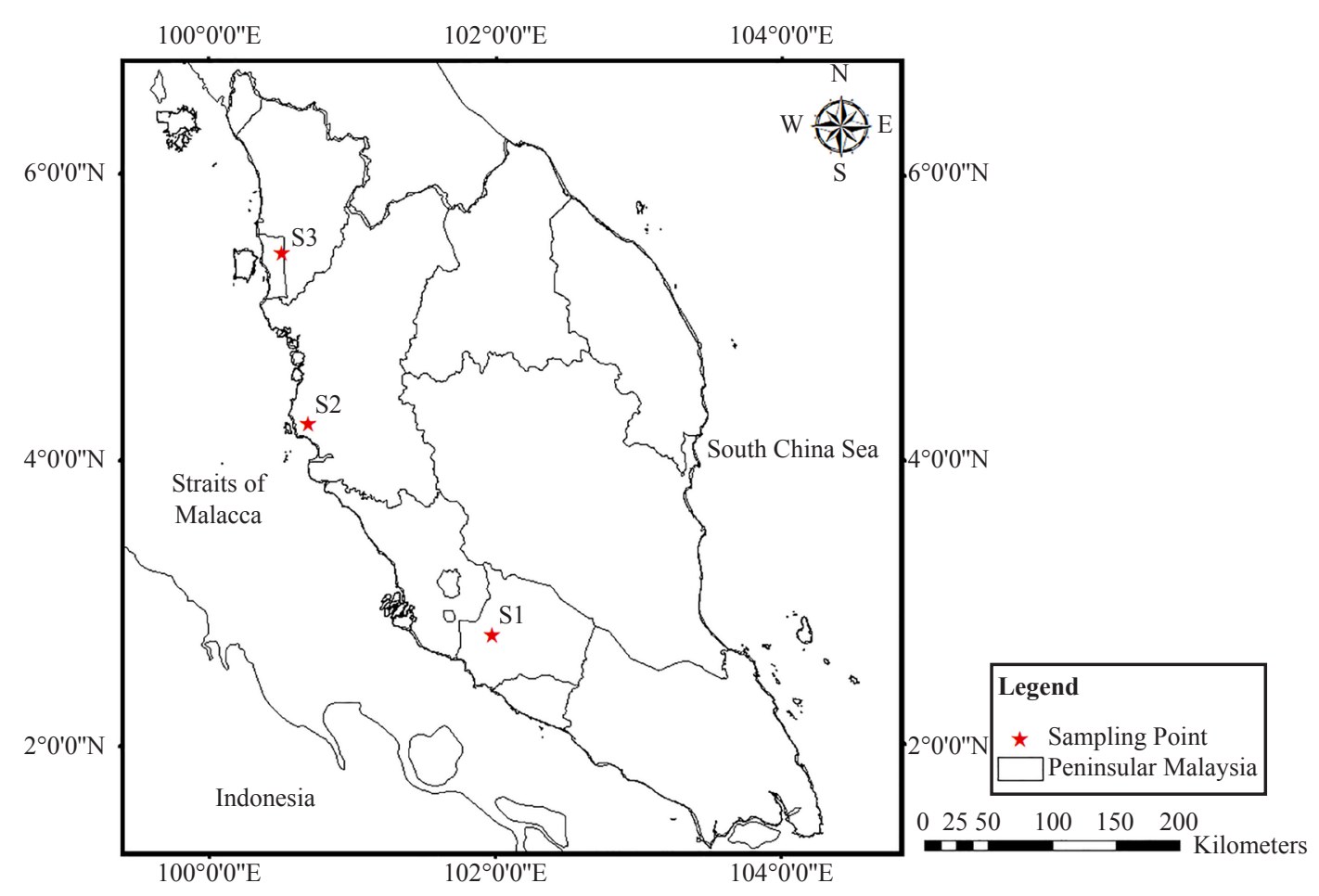

Figure 1. The sampling sites of green mustard Brassica rapa var. parachinensis collection from three different site in Peninsular Malaysia (1 = Sikamat; 2 = Setiawan; 3 = Ara Kuda) 
The samples were then digested with nitric acid through the acid digestion method [14]. Digested samples were filtered and stored in acid-washed pillboxes before they were analyzed for $\mathrm{Cu}, \mathrm{Fe}, \mathrm{Ni}, \mathrm{Pb}$, and $\mathrm{Zn}$ using a flame atomic absorption spectrophotometer (AAS) model Thermo Scientific iCE 3000 series. For calibration, standard solutions for all five metals were made using 1000 ppm stock solutions given by Sigma-Aldrich. All data obtained from the AAS were presented on $\mathrm{mg} / \mathrm{kg}$ dry weight basis.

To avoid external contamination, all glassware used in this investigation were acid-washed for quality assurance and quality control. The analytical procedures and accuracy of the method were checked by using two certified reference materials (CRMs), namely Lagarosiphon major (N.60) and Peach Leaves (NIST 1547). The recoveries are acceptable where they are within 90-120\% of recovery percentages: $97.4,120$, and $119 \%$ for $\mathrm{Zn}, \mathrm{Cu}$, and $\mathrm{Pb}$, respectively by using CRM Lagarosiphon major while the recoveries of Ni, and Fe were 97.0 and 117\%, respectively, by using CRM Peach Leaves (NIST 1547) (Table 1).

Table 1. Comparison of metal concentrations ( $\mathrm{mg} / \mathrm{kg}$ dry weight) between certified and measured values

\begin{tabular}{cccc}
\hline & \multicolumn{3}{c}{ Lagarosiphon major (N.60) } \\
\cline { 2 - 4 } & Certified value & Measured value & Recovery (\%) \\
\hline $\mathrm{Cu}$ & $51.20 \pm 1.9$ & $61.54 \pm 1.4$ & 120.2 \\
$\mathrm{~Pb}$ & $64 \pm 4.00$ & $76.3 \pm 2.40$ & 119 \\
$\mathrm{Zn}$ & $313 \pm 8$ & $304.85 \pm 3.4$ & 97.4 \\
& & Peach Leaves (NIST 1547) & \\
$\mathrm{Fe}$ & 219.8 & 211 & 97.0 \\
$\mathrm{Ni}$ & 0.689 & 0.81 & 117 \\
\hline
\end{tabular}

The current concentrations on a dry weight basis were converted to a wet weight basis for the human health risk assessment due to the fact that the vegetable is consumed on a fresh weight basis. As a result, the current metal concentrations ( $\mathrm{mg} / \mathrm{kg}$ dry weight) were converted to a wet weight basis using a conversion factor of 0.099 for $B$. rapa, as shown in Table 4.

The human health risk considers a one-time or long-term dangerous exposure to metals through a vegetable diet. The estimated daily intake (EDI) values were calculated by using the following formula (equation 1):

$$
\mathrm{EDI}=(\mathrm{Mc} \times \mathrm{CR}) / \mathrm{BW}
$$

where;

$\mathrm{Mc}=$ the metal concentration in $B . \operatorname{rapa}(\mathrm{mg} / \mathrm{kg}$ wet weight $)$;

$\mathrm{CR}=$ the consumption rate of $B$. rapa (232 $\mathrm{g}$ /day for children; $345 \mathrm{~g} /$ day for adults) [15] and,

$\mathrm{BW}=$ body weight (32.7 $\mathrm{kg}$ for children; $55.9 \mathrm{~kg}$ for adults) [16].

In this study, a target hazard quotient (THQ), which is a non-carcinogenic risk assessment method The THQ (USEPA, 2000), was determined based on the following formula (equation 2)

$$
\mathrm{THQ}=\mathrm{EDI} / \mathrm{RfD}
$$

where;

$\mathrm{EDI}=$ estimated daily intake;

$\mathrm{RfD}=$ the oral reference dose, in which $\mathrm{Cu}: 40.0$, Fe: 700, Ni: 20.0, and Zn: 300 were the RfD (g/kg wet weight/ day) values employed in this investigation, which were obtained from the EPA's Integrated Risk Information System online database [17]. Because RfD for Pb was not available (EPA's IRIS, [17]), the current study used the RfD of $4.00 \mathrm{~g} /$ 
$\mathrm{kg}$ wet weight/day [18]. If the THQ ratio is more than one (THQ 1), it is expected that vegetable consumption will result in a non-carcinogenic danger of heavy metals to human health. The metal data for B. rapa were cited from China (Pearl River Estuary; [19]) and Pakistan (Lahore; [20]). These metal data were calculated for EDI and THQ values.

\section{Results and discussion}

Table 2 shows the metal contents in B. rapa (leafy part) taken from three farms in Peninsular Malaysia (mg/kg dry weight).For the leafy edible part, the ranges of metal concentrations (mg/kg dry weight) were $\mathrm{Cu}$ (16.1-18.5), $\mathrm{Fe}(145$ 207), $\mathrm{Ni}(1.02-1.64), \mathrm{Pb}(0.90-2.73)$ and $\mathrm{Zn}(74.0-203)$.

Lead, $\mathrm{Cu}$, and $\mathrm{Zn}$ levels in B. rapa collected from reclaimed tidal flat soils of the Pearl River Estuary, China [19] and two irrigated zones from Lahore, Pakistan [20], were lower than those found from the present study. However, the current study's Ni levels were lower than those reported in the two papers. The mean $\mathrm{Cu}$ and $\mathrm{Zn}$ values in $B$. rapa from the three sites were lower than the maximum acceptable limits specified by FAO/WHO [18] (Zn: $60 \mathrm{mg} / \mathrm{kg} \mathrm{ww}$; Cu: 40 $\mathrm{mg} / \mathrm{kg} \mathrm{ww}$ ) after conversion to wet weight basis.

Table 2. Mean metal concentrations (mg/kg dry weight) in leaves of Brassica rapa var. parachinensis collected from three farms in Peninsular Malaysia. Values in brackets are converted into wet weight basis using a conversion factor of 0.099

\begin{tabular}{|c|c|c|c|c|c|c|c|}
\hline Site & $\mathrm{Cu}$ & $\mathrm{Fe}$ & $\mathrm{Ni}$ & $\mathrm{Pb}$ & $\mathrm{Zn}$ & SD & Reference \\
\hline Sikamat, Seremban. & $16.1(1.61)$ & $207(20.7)$ & $1.02(0.10)$ & $0.90(0.09)$ & $74.0(7.40)$ & 1-Sep-13 & This study \\
\hline Ara Kuda Penang & $18.5(1.85)$ & $145(14.5)$ & $1.64(0.16)$ & $2.73(0.27)$ & $203(20.3)$ & 20-Oct-16 & This study \\
\hline Kg Sitiawan Manjung Perak & $16.9(1.89)$ & $187(18.7)$ & $1.41(0.14)$ & $1.26(0.13)$ & $137(13.7)$ & 26-Oct-16 & This study \\
\hline Pearl River Estuary, China* & 0.443 & NA & 0.26 & 0.106 & 3.29 & - & [19] \\
\hline $\begin{array}{c}\text { Groundwater irrigated zone, } \\
\text { Lahore, Pakistan }\end{array}$ & $0.70(0.07)$ & NA & $2.98(0.30)$ & $0.41(0.04)$ & $2.49(0.25)$ & - & [20] \\
\hline $\begin{array}{l}\text { Wastewater irrigated zone, } \\
\text { Lahore, Pakistan }\end{array}$ & $4.90(0.49)$ & NA & $5.76(0.58)$ & $0.77(0.08)$ & $28.5(2.85)$ & - & {$[20]$} \\
\hline
\end{tabular}

* = in wet weight basis. $\mathrm{NA}=$ data is not available. $\mathrm{SD}=$ sampling date.

Abdel-Farid and El Saady [21] evaluated the HM levels of two kinds of B. rapa native to Egypt (B. rapa var. rapa) and the Netherlands (B. rapa var. Raapstelen) grown under the identical climatic circumstances. The quantities of HMs at any developmental stage were determined to be below the FAO and WHO acceptable standards for human consumption.

\subsection{Health risk assessments}

Tables 3 and 4 provide the EDI and THQ values for the five HMs in B. rapa var. parachinensis for adults and children. In both adults and children, all THQ values for $\mathrm{Fe}, \mathrm{Cu}, \mathrm{Ni}, \mathrm{Pb}$, and $\mathrm{Zn}$ were found to be $<1.00$. This indicated that there were no non-carcinogenic dangers of the five metals from B. rapa diet in the current investigation. THQ values of HMs in children were often greater than those in adults. Zhang et al. [22] found that the THQ values for seven heavy metals including $\mathrm{Pb}, \mathrm{Cu}$, and $\mathrm{Zn}$, in 30 vegetables from Kunming City (China) was $>1.00$ for teenagers, indicating that HMs were non-carcinogenic to consumers of this category. Islam et al. [23] found that THQs for Zn and $\mathrm{Cu}$ in vegetables from Bogra District (Bangladesh) were $<1.00$, implying that consumers would not be exposed to major health risks if they ate a single metal from a single species of vegetable. Ahmad et al. [9] revealed that THQ values for three metals $(\mathrm{Cu}, \mathrm{Ni}$, and $\mathrm{Pb})$ were $>1.001 \mathrm{in}$. rapa obtained from vegetable farms in Sargodha (Pakistan), indicating a substantial danger from consuming these crops. 
Table 3. Values of estimated daily intake of heavy metals in leaves of Brassica rapa var. parachinensis

\begin{tabular}{|c|c|c|c|c|c|c|c|c|c|c|}
\hline & \multicolumn{5}{|c|}{ Adults } & \multicolumn{5}{|c|}{ Children } \\
\hline Consumption rate of vegetables (g/day) & & & 345 & & & & & 323 & & \\
\hline \multirow[t]{2}{*}{ Body weight (kg) } & & & 55.9 & & & & & 32.7 & & \\
\hline & $\mathrm{Cu}$ & $\mathrm{Fe}$ & $\mathrm{Ni}$ & $\mathrm{Pb}$ & $\mathrm{Zn}$ & $\mathrm{Cu}$ & $\mathrm{Fe}$ & $\mathrm{Ni}$ & $\mathrm{Pb}$ & $\mathrm{Zn}$ \\
\hline Seremban & 9.84 & 126 & 0.62 & 0.55 & 45.2 & 15.7 & 203 & 1.00 & 0.88 & 72.4 \\
\hline Ara & 11.32 & 88.5 & 1.00 & 1.67 & 124 & 18.1 & 142 & 1.60 & 2.67 & 199 \\
\hline Manjung & 10.32 & 114 & 0.86 & 0.77 & 83.43 & 16.5 & 183 & 1.38 & 1.23 & 134 \\
\hline Pearl River Estuary, China* & 2.73 & NA & 1.58 & 0.65 & 20.30 & 4.38 & NA & 2.53 & 1.05 & 32.5 \\
\hline Groundwater irrigated zone, Lahore, Pakistan** & 0.45 & NA & 1.80 & 0.20 & 2.69 & 0.72 & NA & 2.88 & 0.31 & 4.30 \\
\hline Wastewater irrigated zone, Lahore, Pakistan** & 2.74 & NA & 1.80 & 1.01 & 21.65 & 4.39 & NA & 2.88 & 1.62 & 34.7 \\
\hline
\end{tabular}

Note: All metal data were converted to wet weight basis using a conversion factor of 0.099 for the calculation of EDI.

* = the data were not converted since the data is already in wet weight basi.

$\mathrm{NA}=$ data is not available.

*Li et al. [19].

** Mahmood and Malik [20].

Table 4. Values of target hazard quotient of heavy metals in the leaves of Brassica rapa var. parachinensis

\begin{tabular}{|c|c|c|c|c|c|c|c|c|c|c|}
\hline \multirow[b]{2}{*}{$\mathrm{RfD}(\mu \mathrm{g} / \mathrm{kg}$ wet weight/day) } & \multicolumn{5}{|c|}{ Adults } & \multicolumn{5}{|c|}{ Children } \\
\hline & 40.0 & 700 & 20.0 & 4.00 & 300 & 40.0 & 700 & 20.0 & 4.00 & 300 \\
\hline & $\mathrm{Cu}$ & $\mathrm{Fe}$ & $\mathrm{Ni}$ & $\mathrm{Pb}$ & $\mathrm{Zn}$ & $\mathrm{Cu}$ & $\mathrm{Fe}$ & $\mathrm{Ni}$ & $\mathrm{Pb}$ & $\mathrm{Zn}$ \\
\hline Seremban & 0.246 & 0.181 & 0.031 & 0.137 & 0.151 & 0.394 & 0.290 & 0.050 & 0.220 & 0.241 \\
\hline Ara & 0.283 & 0.126 & 0.050 & 0.417 & 0.414 & 0.453 & 0.202 & 0.080 & 0.667 & 0.662 \\
\hline Manjung & 0.258 & 0.163 & 0.043 & 0.192 & 0.278 & 0.413 & 0.262 & 0.069 & 0.308 & 0.445 \\
\hline Pearl River Estuary, China* & 0.068 & NA & 0.079 & 0.164 & 0.068 & 0.109 & NA & 0.126 & 0.262 & 0.108 \\
\hline $\begin{array}{c}\text { Groundwater irrigated zone, Lahore, } \\
\text { Pakistan*** }\end{array}$ & 0.011 & NA & 0.090 & 0.049 & 0.009 & 0.018 & NA & 0.144 & 0.078 & 0.014 \\
\hline $\begin{array}{c}\text { Wastewater irrigated zone, Lahore, } \\
\text { Pakistan** }\end{array}$ & 0.069 & NA & 0.090 & 0.254 & 0.072 & 0.110 & NA & 0.144 & 0.406 & 0.116 \\
\hline
\end{tabular}

$\mathrm{NA}=$ data is not available. $*$ Li et al. [19]. ** Mahmood and Malik [20].

\section{Conclusion}

The current HM concentrations in B. rapa var. parachinensis. were evaluated for potential health hazards. In conclusion, the current investigation found no non-carcinogenic hazards of $\mathrm{Cu}, \mathrm{Fe}, \mathrm{Ni}, \mathrm{Pb}$, and $\mathrm{Zn}$ from consuming $B$. rapa. Nonetheless, the current findings highlighted the importance of routine HM monitoring and risk assessment as changes in the environment is dynamic and will aggravate as anthropogenic activities continues to develop. Therefore, it is recommended to conduct annual monitoring on B. rapa to prevent metal contamination.

\section{Acknowledgement}

The authors gratefully thank some financial support from the Malaysian Ministry of Higher Education's 
Fundamental Research Grant Scheme (FRGS), [Vote no.: 5524953].

\section{References}

[1] Yaacob A, Yap CK, Omar H, Aris AZ, Latif MT. Health risks of essential Cu and Zn via consumption of vegetables and relationships with the habitat topsoils from three farming areas of Peninsular Malaysia. In: Yap CK (ed.) Soil Pollution: Sources, Management Strategies and Health Effects. New York: Nova Science Publishers; 2019. p. 229260.

[2] Yaacob A, Yap CK, Nulit1 R, Omar1 H, Al-Shami SA, Bakhtiari AR. A comparative study of health risks of Fe and $\mathrm{Ni}$ in the vegetables collected from selected farming areas of peninsular malaysia. Journal of Aquatic Pollution and Toxicology. 2018; 2: 21.

[3] Yaacob A, Chee KY, Nulit R, Omar H, Al-Shami SA, Riyahi Bakhtiari A. Assessment of health risks of the toxic Cd and $\mathrm{Pb}$ between leafy and fruit vegetables collected from selected farming areas of Peninsular Malaysia. Integrative Food, Nutrition and Metabolism. 2018; 5: 1-9. Available from: https://doi.org/10.15761/IFNM.1000215.

[4] Yap CK, Yaacob A, Hafiz M, Nulit R, Chee S, Chee SL. Heavy metals in bitter dourd (Momordica charantia): Human health risk assessment. ARC Journal of Nutrition and Growth. 2019; 5: 1-5. Available from: https://doi. org/10.20431/2455-2550.0501001.

[5] Yap CK, Zaid MZC, Nulit R, Leow CS. Heavy metals (Cu, Ni and Zn) in chili (Capsicum annuum) collected from selected farms in Selangor and their human health risk assessments. EC Nutrition. 2019; 15: 1-6.

[6] Yap CK, Yaacob A, Wong KW, Nulit R, Nallapan M, Mohd MH, et al. Human health risks of heavy metals in okra (Abelmochus esculentus) and lettuce (Lactuta sativa) collected from selected farms in Peninsular Malaysia. Food Science \& Nutrition Technology. 2019; 4: 180.

[7] Girisha ST, Ragavendra VB. Accumulation of heavy metals in leafy vegetables grown in urban areas by using sewage water and its effect. Archives of Phytopathology and Plant Protection. 2009; 42: 956-959. Available from: https://doi.org/10.1080/03235400701543806.

[8] Khan S, Cao Q, Zheng YM, Huang YZ, Zhu YG. Health risks of heavy metals in contaminated soils and food crops irrigated with wastewater in Beijing, China. Environmental Pollution. 2008; 152: 686-692. Available from: https:// doi.org/10.1016/j.envpol.2007.06.056.

[9] Ahmad K, Ashfaq A, Khan ZI, Bashir H, Sohail M, Mehmood N, et al. Metal accumulation in Raphanus sativus and Brassica rapa: an assessment of potential health risk for inhabitants in Punjab, Pakistan. Environmental science and pollution research international. 2018; 25: 16676-16685. Available from: https://doi.org/10.1007/s11356-0181868-7.

[10] Wang Y, Qiao M, Liu Y, Zhu Y. Health risk assessment of heavy metals in soils and vegetables from wastewater irrigated area, Beijing-Tianjin city cluster, China. Journal of Environmental Sciences. 2012; 24: 690-698. Available from: https://doi.org/10.1016/S1001-0742(11)60833-4.

[11] Chin HF, Yap EE. Malaysian vegetables in colour: A complete guide. Kuala Lumpur, Malaysia: Tropical Press; 1999.

[12] Prohens-Tomás J, Nuez F. Vegetables I: Asteraceae, Brassicaceae, Chenopodicaceae, and Cucurbitaceae. New York: Springer-Verlag; 2008. Available from: https://doi.org/10.1007/978-0-387-30443-4.

[13] Prohens-Tomás J, Nuez F. Vegetables II: Fabaceae, Liliaceae, Solanaceae, and Umbelliferae. New York: SpringerVerlag; 2008. Available from: https://doi.org/10.1007/978-0-387-74110-9.

[14] Yap CK, Cheng WH, Wong KW, Yaacob A, Razalai R, Leow CS, et al. Health risks of essential Ni and Fe via consumption of water spinach Ipomoea aquatica collected from Peninsular Malaysia. Annals of Environmental Science and Toxicology. 2020; 4: 1-4. Available from: https://doi.org/10.17352/aest.000018.

[15] Dong QN, Wu JH, Jia M. An analysis of meals nutrients of children below 14 years old in Tianjin, China. Chronic Illn Prev Control. 1996; 6: 138-139.

[16] Wang X, Sato T, Xing B, Tao S. Health risks of heavy metals to the general public in Tianjin, China via consumption of vegetables and fish. Science of the Total Environment. 2005; 350: 28-37. Available from: https:// doi.org/10.1016/j.scitotenv.2004.09.044.

[17] US EPA. Integrated Risk Information System (IRIS). Washington DC, United States: U.S. Environment Protection Agency; 2008.

[18] FAO/WHO. Guidelines for the Safe Use of Wastewater and food stuff. Switzerland: World Health Organization; 2013. 
[19] Li Q, Chen Y, Fu H, Cui Z, Shi L, Wang L, et al. Health risk of heavy metals in food crops grown on reclaimed tidal flat soil in the Pearl River Estuary, China. Journal of Hazardous Materials. 2012; 227-228: 148-154. Available from: https://doi.org/10.1016/j.jhazmat.2012.05.023.

[20] Mahmood A, Malik RN. Human health risk assessment of heavy metals via consumption of contaminated vegetables collected from different irrigation sources in Lahore, Pakistan. Arabian Journal of Chemistry. 2014; 7: 91-99. Available from: https://doi.org/10.1016/j.arabjc.2013.07.002.

[21] Abdel-Farid I, El-Saady M. Heavy metal and element profiling of Brassica rapa. Journal of Consumer Protection and Food Safety. 2013; 8: 201-204. Available from: https://doi.org/10.1007/s00003-013-0830-3.

[22] Zhang H, Huang B, Dong L, Hu W, Akhtar MS, Qu M. Accumulation, sources and health risks of trace metals in elevated geochemical background soils used for greenhouse vegetable production in southwestern China. Ecotoxicology and Environmental Safety. 2017; 137: 233-239. Available from: https://doi.org/10.1016/ j.ecoenv.2016.12.010.

[23] Islam MdS, Ahmed MdK, Habibullah-Al-Mamun Md. Apportionment of heavy metals in soil and vegetables and associated health risks assessment. Stochastic Environmental Research and Risk Assessment. 2016; 30: $365-377$. Available from: https://doi.org/10.1007/s00477-015-1126-1. 